\section{EVALUATION OF COMBINED PRODUCTION OF HEAT AND ELECTRICITY ON THE
COGENERATION UNIT}

MIROSLAV RIMAR, MARCEL FEDAK, ANDRII KULIKOV, MILAN ABRAHAM

Technical University of Kosice, Faculty of Manufacturing Technologies with a seat in Presov, Department of Process Technique, Presov, Slovakia

DOI: 10.17973/MMSJ.2021_12_2021099

e-mail: andrii.kulikov@tuke.sk

The purpose of currently contribution is to analyse and compare effectivity of cogeneration unit in each summer and winter season. The main idea of combined heat and energy production is to reduce usage of primary fuels and with that connected reduction of pollutions due to the integration of renewable energy sources and with regard to the natural environment. Presented contribution is dedicated on issue on the operation of a cogeneration unit integrated in central heating system.

KEYWORDS

efficiency, cogeneration, energy, heat, CHP

\section{INTRODUCTION}

The production of heat and electricity can be carried by many different ways. For heat generation, there are technologies that allow production of electricity on the same equipment at the same time by combustion natural gas in combustion engine. This type of production is called combined production of heat and electricity (CHP).

The Council of the European Union started promoting the CHP concept in 1974. Term combined heat and power supply nowadays is becoming and important issue for power generation management [Abraham 2018]. Integration of cogeneration systems and renewable energy for heat generation on the basis of act No. 309/2009 is becoming an important part of the energy generation [Act 309/2009].

When implementing energy sources, it is necessary to consider with implementation directive of the European parliament and of the Council of EU 2012/27/EU on energy efficiency [Act 309/2009, Directive 2004].

A combined heat and power (CHP) system is proposed to minimize the production cost and to maximize the revenue from produced power. CHP is considered a sustainable and economic technology. To fulfil those abovementioned goals for its significant performance in primary fuel consumption reduction, pollutions reduction and independency on fossil fuel [Dvorsky 2005, Krbek 2013].

Heat supply nowadays requires part of primary energetic source and easiest way is to burn right fuel and by transfer send to heat customer. Effectivity of this transformation is high (80 - $100 \%)$ but it loses exergy of fuel [Rimar 2013a, Struz 2014].

\section{ANALYSIS OF COMBINED HEAT AND POWER SYSTEMS}

This paper analyses exploitation of cogeneration unit in normal operation during all seasons and compares energy production efficiency. Presented cogeneration unit heats and prepares hot water for about 1600 apartments, elementary school and shopping centres. Cogeneration unit itself consists of gas combustion engine MWM/TCG 2016 V12C with generator which provides $600 \mathrm{~kW}$ of electrical rated power and $652 \mathrm{~kW}$ of thermal nominal power [Rimar 2013b, Gvozdenac 2017, Abraham 2018].

Engine with generator are connected in one unit using the elastic silent block attached to the frame as shown at Figure 1.
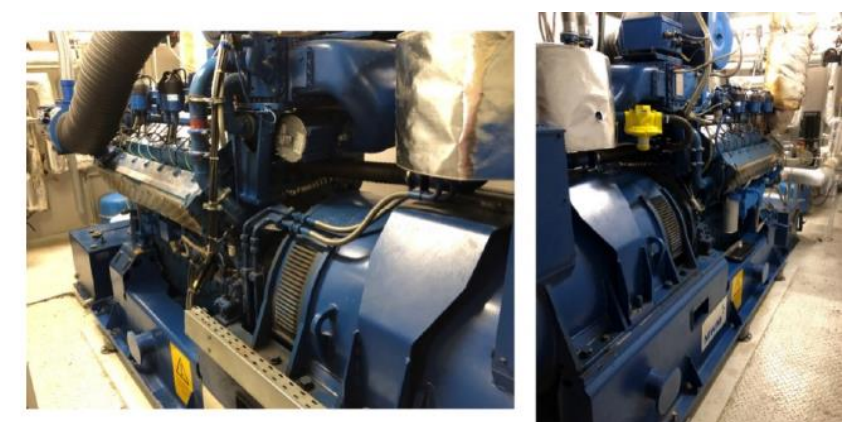

Figure 1. Cogeneration unit engine with generator

Electrical energy is used for supply cogeneration unit parts such as compressors, pumps and many other components included in container (Fig. 2) and whole cogeneration system. On Figure 2 is shown container with cogeneration unit. Described cogeneration unit is working in fully automatic operation cycle. This type of operation means that it is controlled by microprocessors which evaluate needed heat and electricity. Human factor in this point is only to control if system is working properly and there are no special factors for system failure.

There are some restrictions for described cogeneration systems in energy productions. System is limited mostly in summer days. There are not high requirements for heat and hot water. In case of this problem, cogeneration is not working on $100 \%$ of its power. Limitation for heat producing also has an impact for electricity production in case of not $100 \%$ operation. Regarding to electricity production there are also restrictions. Main restriction is in limitation of electricity production to local energy provider. It is necessary to calculate energy needs of surroundings to avoid limited operation of cogeneration system and decrease efficiency of energy production.

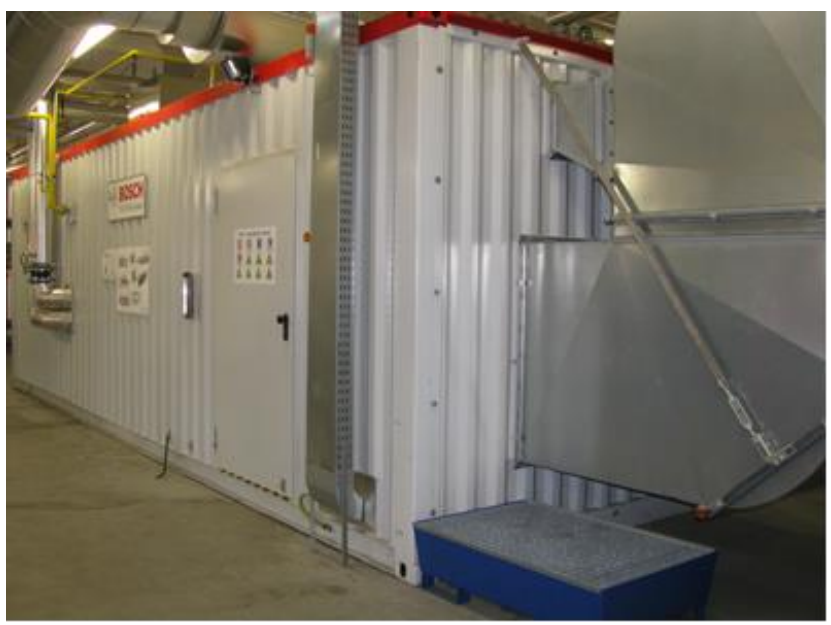

Figure 2. Container with cogeneration unit included inside 
Fuel (Monthly) consumption is shown in Figure 3 which confirms that there is less consumption in summer seasons and with that connected less electricity production and more heat. Values shows that cogeneration unit in summer season is significantly ineffective and in winter season effectivity is average $85 \%$. Tab. 1 shows statistics in 2017 - total heat and electricity produced by described cogeneration unit; fuel consumption and calorific value for each month in year [SPP 2021, Rimar 2013c].

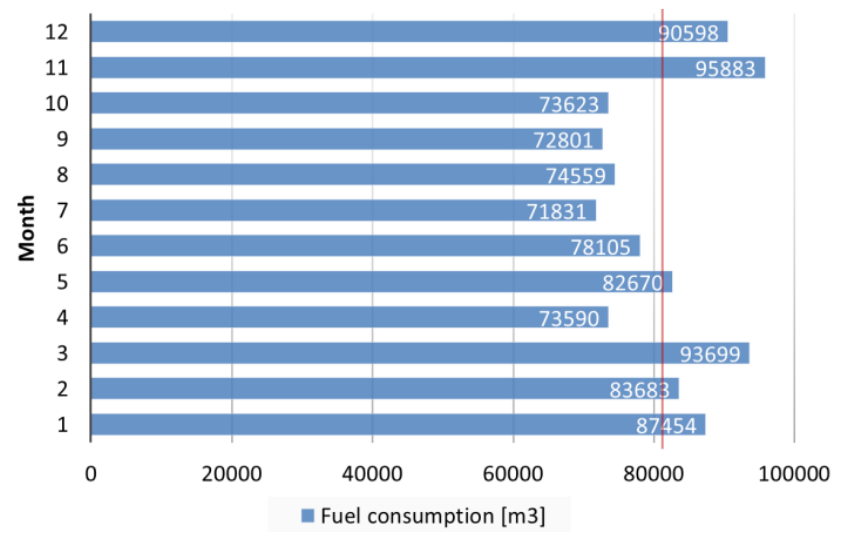

Figure 3. Fuel consumption of cogeneration unit in $2017\left[\mathrm{~m}^{3}\right]$

Table 1. Produced electricity and heat, consumed fuel and calorific value 2017

\begin{tabular}{|l|c|c|c|c|}
\hline & $\begin{array}{c}\text { Heat } \\
{[\mathrm{MWh}]}\end{array}$ & $\begin{array}{c}\text { Electricity } \\
{[\mathrm{MWh}]}\end{array}$ & $\begin{array}{c}\text { Fuel } \\
{\left[\mathrm{m}^{3}\right]}\end{array}$ & $\begin{array}{c}\text { Lower } \\
\text { heating value } \\
{[\mathrm{kWh.m} \text {-3] }}\end{array}$ \\
\hline January & 404.06 & 341.4 & 87454 & 9.688 \\
\hline February & 368.1 & 327.6 & 83683 & 9.677 \\
\hline March & 437.37 & 367.9 & 93699 & 9.698 \\
\hline April & 352.36 & 290.3 & 73590 & 9.742 \\
\hline May & 392.78 & 324.57 & 82670 & 9.728 \\
\hline June & 372.71 & 305.3 & 78105 & 9.742 \\
\hline July & 342.05 & 278.6 & 71831 & 9.742 \\
\hline August & 353.29 & 288.6 & 74559 & 9.709 \\
\hline September & 343.81 & 281.1 & 72801 & 9.725 \\
\hline October & 344.31 & 281.5 & 73623 & 9.689 \\
\hline November & 455.38 & 369.4 & 95883 & 9.678 \\
\hline December & 426.62 & 348.3 & 90598 & 9.698 \\
\hline Average & 382.74 & 317.05 & 81541 & 9.710 \\
\hline
\end{tabular}

\subsection{Heat production in CHP system}

Natural gas is one of the dominant fuels for heat production. This fact is also a reason for needs to be placed on CHP systems and directly with that connected to cogeneration. As shown in table, there is a direct correlation between heat and electricity production. Due to non-economical operation there is less electricity production because there is no need for much heat in summer season. The cogeneration unit circuit is connected to storage tanks of $2 \times 63 \mathrm{~m}^{3}$.

For heat production is used the heat of exhausted gases which is around $460{ }^{\circ} \mathrm{C}$, heat from cooling engine approximately $90{ }^{\circ} \mathrm{C}$ and heat of cooling of the fuel mixture approximately $40^{\circ} \mathrm{C}$.

Detailed production of heat and electricity is shown in Figures 4 and 5 for each month in 2017. There are different values of produced energy for each month. This fact means there are different efficiency for each produced electricity and heat for each month.
Cogeneration unit in summer season needs to be cooled more than in winter season, this is one of main reasons that production of electricity is limited as shown in Figure 5. The Cumulated heat and electricity efficiency is shown at Figure 6.

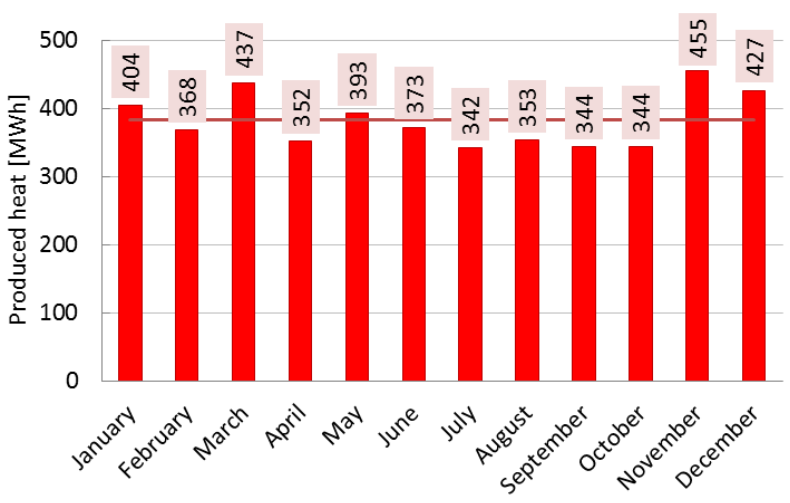

Figure 4. Produced heat 2017 [MWh]

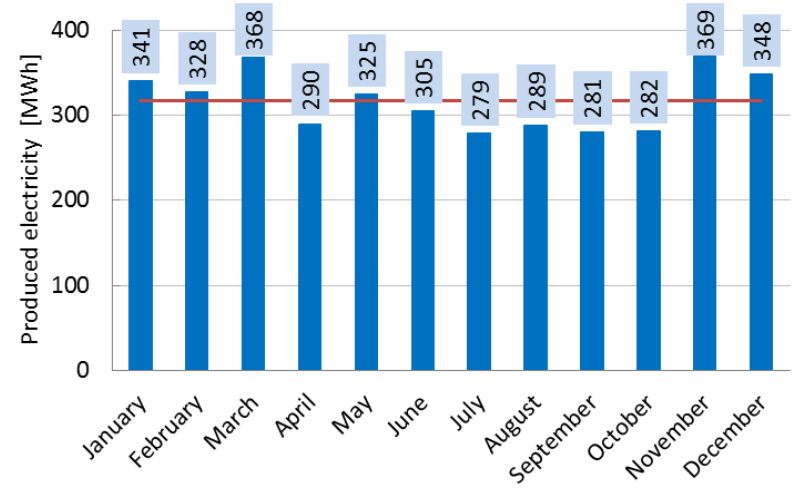

Figure 5. Produced electricity 2017 [MWh]

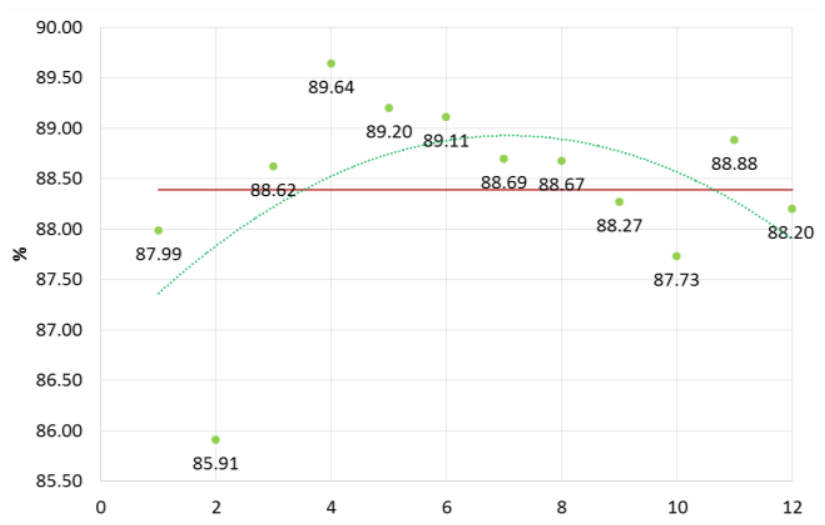

Figure 6. Cumulated heat and electricity efficiency [\%]

Figures 7 and 8 describe sequence of efficiency. The highest efficiency for electricity is in the beginning of year since there is not high limitation for cogeneration unit operation. Compared to summer season where is no need for heat and due to this fact operation is limited that has impact for electricity production. 


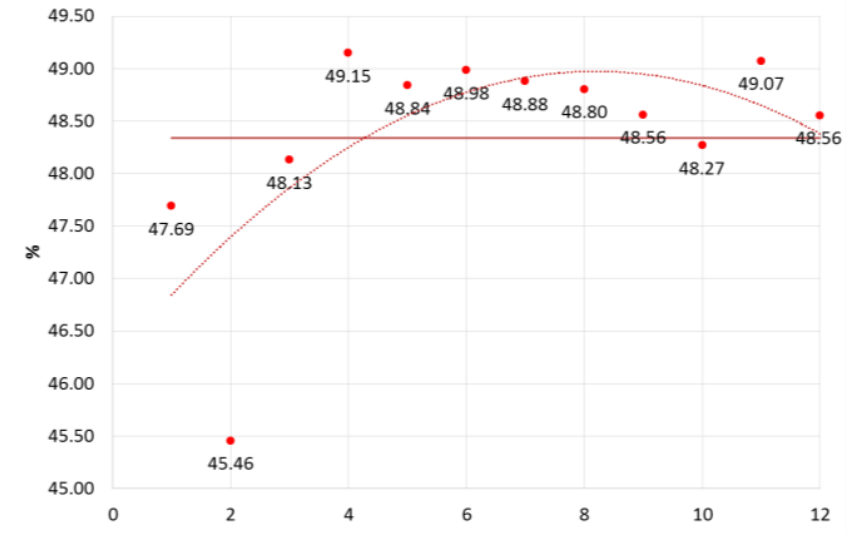

Figure 7. Heat efficiency [\%]

The heat transfer is provided through the plate exchangers located in the cogeneration unit container (Fig. 2) and the flue gas exchanger located behind the cogeneration unit container.

Source of electricity is synchronous three-phase generator which provides $600 \mathrm{~kW}$ operating at $400 \mathrm{~V}$. Works with a controlled power factor $\phi>95$. The generator is equipped with complete accessories such as generator protection, mains and switching elements, switchgear and control of its own consumption.

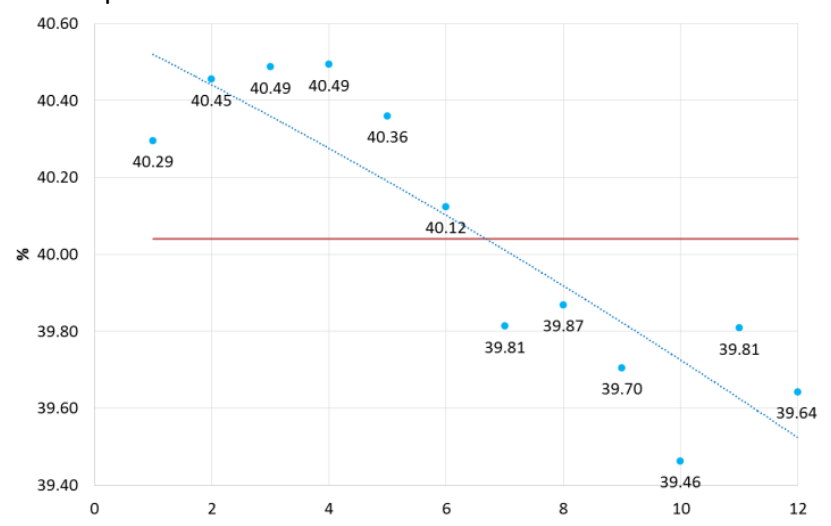

Figure 8. Electricity efficiency [\%]

Heat /Electricity ratio consumption is shown at Figure 9.

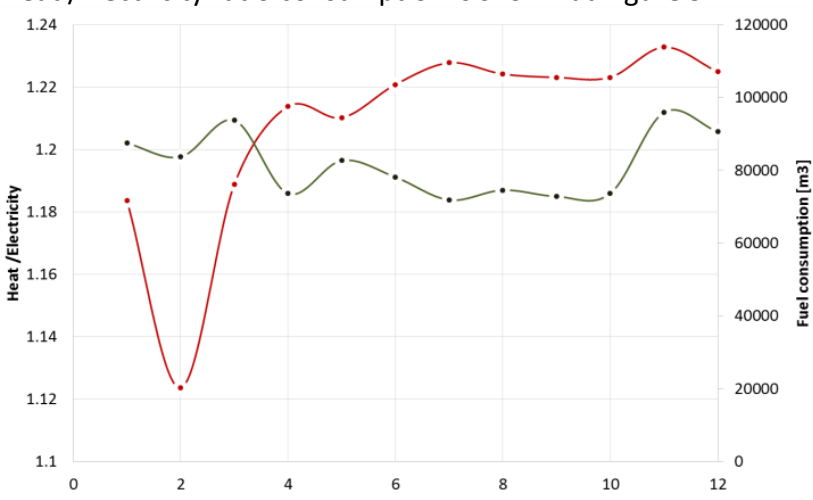

Figure 9. Heat /Electricity ratio - Fuel consumption
Average electricity efficiency production was around $40.04 \%$. On Figure 8 there is described produced electricity and heat separately. As shown, there is a direct correlation between the generated electrical energy and the heat.

Average electricity production was around $317.05 \mathrm{MWh}$. Average produced heat is $360.48 \mathrm{MWh}$ and heat from cooling 24.29 MWh. In total around 407.2 MWh.

As can be seen, there is a direct correlation between produced electricity and heat compared to fuel consumption, its own synchronization control and external networking. Measurements are ensured by measuring current and voltage transformers on the side of the switchboard [Murcinkova 2013]. Monitored value of produced electric energy and heat is shown in Figure 9 separately. Total average effectivity of monitored cogeneration unit is around $88.39 \%$ or $91.45 \%$ (Cumulated produced heat, heat from fuel cooling and electric energy). The priority on the production of cogeneration unit is in thermal energy as shown in the figures. Overall power of cogeneration unit was not recorded; the only recorded values are shown at figures.

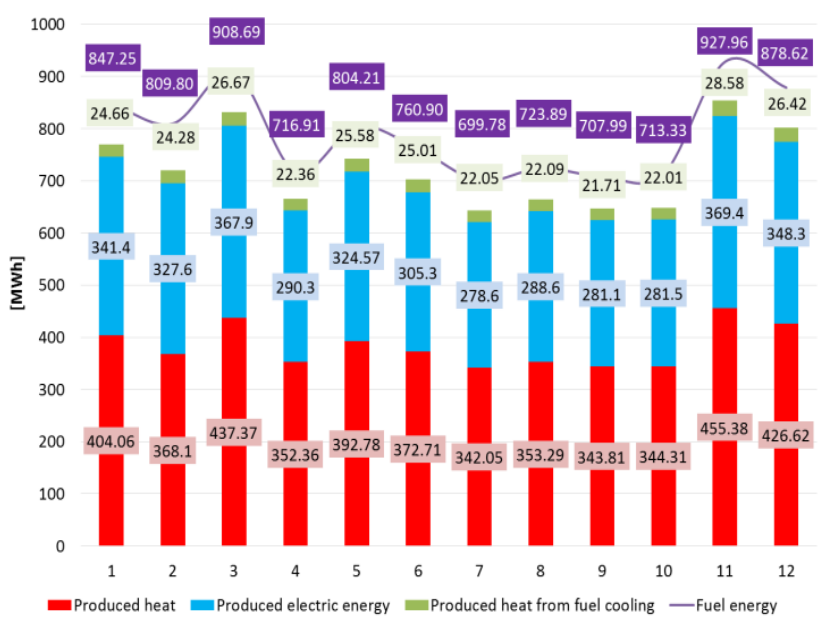

Figure 10. Comparison of produced electricity and heat [MWh]

When operating the cogeneration unit engine, increased attention should be paid to the operating substances which are natural gas, engine oil, cooling liquids and demineralized water. Samples are taken at regular intervals and analysed and in case of necessary supplemented or exchanged [Directive 2004]. 


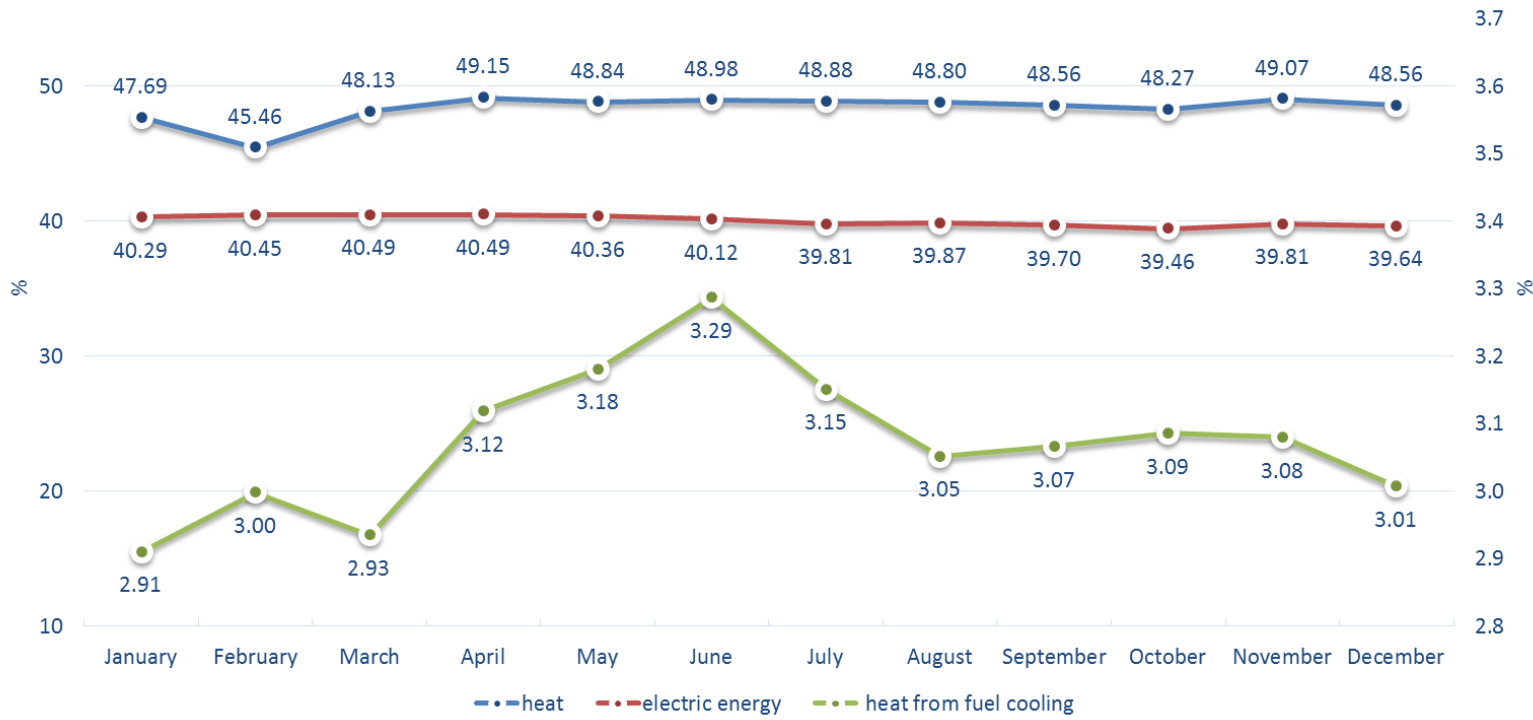

Figure 10. Effectivity of each energy production separately [\%]

The main idea of the article was to determine the CHP unit effectivity and to compare the effectivity in summer and winter conditions. The ration of the effectivity of the production of electric energy and heat are shown at the Figure 10. According to the measured data there were determined that the difference of effectivity of the electric energy production was almost negligible while the heat production was changed due to the difference of the fuel and combustion air temperature.

\section{CONCLUSIONS}

Considering the EU policies and directives the natural gas will stay the dominant fuel in the European energy package so the greater emphasis need to be placed on combined energy production methods which are directly connected to CHP. The analysis of the production parameters of the measured cogeneration unit showed the average year effectivity of the process were $88.39 \%$ or $91.45 \%$ (Cumulated produced heat, heat from fuel cooling and electric energy). Nevertheless, such effectivity was determined as low due to the restrictions of the electricity production capacities. Also was determined that heat production from the fuel cooling is a primary part of the heat production in the summer period while is almost negligible in the winter period.

\section{ACKNOWLEDGMENTS}

This work was supported by the Slovak Research and Development Agency under the contract No. APVV-16-0192.

\section{REFERENCES}

[Abraham 2018] Abraham, M., Fedak, M., Kulikov, A., Smeringai, P., Vahovsky, J. Evaluation of efficiency CHP systems for electric energy production. Advances in Thermal Processes and Energy Transformation, 2018, Vol. 1, No. 2, pp. 27-30.

[Act 309/2009] Act No. 309/2009 Coll. on promotion of renewable energy sources and high efficiency combined generation, and on amendments and supplements of certain Acts in the version of latter provisions, 2009.
[Directive 2004] Directive 2004/8/EC of the European Parliament and of the Council of 11 February 2004 on the promotion of cogeneration based on a useful heat demand in the internal energy market and amending Directive 92/42/EEC, 2004.

[Dvorsky 2005] Dvorsky, E. Hejtmankova, P. Combined production of electrical and heat energy (Kombinovaná výroba elektrické a tepelné energie). BEN - Technicka literatura, 2005, 287 p. (in Czech)

[Gvozdenac 2017] Gvozdenac, D., Urosevic, B., Menke, C. High efficiency cogeneration: CHP and non-CHP energy. Energy, 2017, Vol. 135, pp. 269-278.

[Krbek 2013] Krbek, J., Ochrana, L. Polesny, B. Heat supply and cogeneration. Brno, 2013.

[Murcinkova 2013] Murcinkova, Z., Krenicky, T. Implementation of virtual instrumentation for multiparametric technical system monitoring. In: SGEM 2013: 13th Int. Multidisciplinary Sci. Geoconf. Vol. 1: 16-22 June, 2013, Albena, Bulgaria. Sofia: STEF92 Technology, 2013. pp. 139-144. ISBN 978-954-91818-9-0.

[Panda 2020] Panda, A., Aloshyn, V., Dyadyura, K., Pandova, I., Zaborowski, T. Research of corrosion-mechanical damages and destructions of pipe designs of heat exchangers of cooling systems. In: Manufacturing Engineering. PAS: Poznan, Poland. 2020, IRSE, pp. 51-57. ISBN 978-83-66246-21-8.

[Rimar 2013a] Rimar, M., Skok, P. Thermomechamics. TU Kosice, 2013.

[Rimar 2013b] Rimar, M., Fedak, M., Corny, I. Analysis and synthesis of heating systems control (Analyza a syntéza riadenia tepelnych sustav). TU Kosice, 2013. (in Slovak)

[Rimar 2013c] Rimar, M., Fedak, M. Combustion processes. TU Kosice, 2014.

[SPP 2021] Values of weighted averages of qualitative parameters of natural gas distributed by the SPP company in the territory of the Slovak Republic, 2021.

[Struz 2014] Struz, M. Utilization of CHP in Slovakia and its further outlook, 2014. 


\section{CONTACTS}

Prof. Ing. Miroslav Rimar, CSc.

Assoc. Prof. Ing. Marcel Fedak, PhD.

Ing. Andrii Kulikov, PhD.

Ing. Milan Abraham PhD.

Technical University of Kosice

Faculty of Manufacturing Technologies with a seat in Presov

Department of Process Technique,

Sturova 31, 08001 Presov, Slovak Republic

tel.: +421-55-602-6341

e-mail:miroslav.rimar@tuke.sk,marcel.fedak@tuke.sk, andrii.kulikov@tuke.sk,milan.abraham@tuke.sk 